ACCOUNTANCY, ALCEMEEN - ACCOUNTANTSCONTROLE - MARKETING

\title{
Kwaliteitsperceptie en accountantsdiensten
}

\section{Een analyse van de $\mathrm{kwaliteitskloof}$}

\author{
Drs. E.A.M. Olders
}

De kwaliteit van accountantsdiensten stal de laatste jaren herhaaldelijk ter discussie. Veranderende maatschappelijke verwachtingen en de wellhaast permanente pressie tot het tonen van toegevoegde waarde in een sterk concurrerende markt staan hierbij centraal. Eind 1995 promoveerde collega Dassen aan de Rijksuniversiteit Limburg (Universiteit Maastricht) op het proefschrift 'Audit Quality: An Empirical Study of the Attributes and Determinants of Audit Quality Perceptions' waarin hij door middel van een empirisch onderzoek onder meer aantoont dat, naast technische $k$ waliteitselementen, functionele $k$ waliteitselementen een belangrijke invloed kunnen hebben op het kwaliteitsoordeel (zie ook het januari-februari-nummer 1997 van het MAB). Op basis van beide soorten kwaliteitselementen wordt in dit artikel het kwaliteitsprobleem conceptueel en empirisch nader onderzocht.

\section{Inleiding}

De kwaliteit van accountantsdiensten laat regelmatig te wensen over! Althans, dat lijkt de boodschap te zijn die volgt uit de vele rapporten en artikelen die het laatste decennium over kwaliteit bij accountants zijn verschenen. Diverse studies tonen aan dat er op bepaalde gebieden discrepanties bestaan tussen wat de opdrachtgevers en de gebruikers van verantwoordingen verwachten en wat ze vinden dat ze daadwerkelijk krijgen (zie ook Porter, 1991; Limperg Instituut,

Drs. E.A.M. Olders RA is werkzaam als Internal Auditor bij Océ. Tevens verricht hij promotieonderzoek bij het Maastricht Accounting \& Auditing Research Center, Universiteit Maastricht.
1987 en Epstein et al. 1994). Dat is wellicht niet verwonderlijk. De markt voor accountantsdiensten wordt de laatste jaren steeds meer getergd door toenemende budgetdruk. Kwaliteit en prijs verhouden zich hierbij min of meer als de kip en het ei. Sterke prijsconcurrentie kan leiden tot een bedreiging voor de kwaliteit en/of juist een symptoom vormen voor een daling in de $\mathrm{kwal}$ teitsperceptie. Toenemende aandacht voor functionele kwaliteitsfacetten lijkt in dit opzicht perspectief te bieden.

In dit artikel staat de kwaliteitsproblematiek omtrent accountantsdiensten centraal. Ik richt mij daarbij hoofdzakelijk op de openbare accountant in diens attest-functie. De kwaliteitskloven worden bekeken op basis van de perceptie van de afnemers van de diensten (in casu enerzijds de cliënten en anderzijds het publieke verkeer). Teneinde methoden te kunnen bepalen voor het dichten van de kloven, zal de kwaliteitskloof conceptueel worden ontrafeld in een aantal subkloven. Daarbij komt eveneens de algemeen onderkende verwachtingskloof ter sprake. Mogelijkheden voor hel dichten van de kwaliteitskloven worden vervolgens kort besproken. Met behulp van onderzoeksdata uit de door Dassen (1995) gehouden enquête onder cliënten en bankiers wordt ten slotte een empirische analyse uitgevoerd ter bepaling van de aanwezigheid en relatieve omvang van kwaliteitskloven.

\section{Kwaliteit en accountants}

Er bestaat geen eenduidige, allesomvattende definitie voor het begrip kwaliteit. Verscheidene definities zijn in de loop der tijd ontwikkeld. De vigerende defïnities hebben echter een duidelijke 
overeenkomst: de geleverde prestatie wordt getoetst aan een bepaalde norm. Kwaliteit is dus een relatief begrip. Als norm voor de kwaliteit van accountantsdiensten zou men de verwachtingen of de wensen van de afnemers kunnen definiëren. Kwaliteit leveren betekent het voldoen aan deze normen, en deze desgewenst overtreffen. ${ }^{2}$ In dit opzicht wordt door twee afnemersgroepen kwaliteit van de publieke accountant verwacht, te weten de verantwoordingsplichtige en het maatschappelijk verkeer. Door de aanwezigheid van tegenstrijdige belangen (en de daarmee gepaard gaande uiteenlopende wensen) zal de kwaliteitsbeleving van deze twee groepen soms divergeren. De empirie in paragraaf 6 bevestigt dit.

Op basis van het verband tussen de definities van kwaliteit kan 'het voldoen aan de verwachtingen' als kwaliteit in enge zin, en 'het voldoen aan de wensen' als kwaliteit in ruime zin worden beschouwd. Immers de wensen zullen in het algemeen de verwachtingen te boven gaan. Het werken met verwachtingen en wensen impliceert dat het kwaliteitsbegrip een subjectief karakter krijgt. Daarnaast is voor de beheersing van de kwaliteit van accountantsdiensten primair de kwaliteitsperceptie van de afnemers van belang. Dit versterkt de subjectiviteit van het kwaliteitsoordeel. Bovendien veranderen wensen en verwachtingen in de loop der tijd waardoor het kwaliteitsconcept een dynamisch karakter krijgt.

Vanuit het oogpunt van kwaliteitsmanagement is met name het gebrek aan kwaliteit interessant. Kwaliteitsgebrek heeft betrekking op dat deel van de wensen respectievelijk verwachtingen waarin de gepercipieerde prestatie níet voorziet. Deze discrepantie kan men als kwaliteitskloof aanduiden. Analoog aan de indeling van de kwaliteitsdefinities onderscheid ik een kwaliteitskloof in ruime zin (voor wat betreft de wensen) en een $k$ waliteitskloof in enge zin (voor wat betreft de verwachtingen). Deze nuancering is naar mijn mening op zijn plaats. Wensen hebben betrekking op het functioneren van de ideale accountant; verwachtingen zijn daarentegen beperkt tot het goed functioneren van de huidige accountant. De ideale accountant overtreft (gewenst) de verwachtingen. Het concept van de kwaliteitskloof in enge zin wordt ook wel aangeduid als de alom bekende verwachtingskloof (zie ook Blokdijk, 1989; Porter, 1991; Berendsen, 1991 en Epstein et al.,
1994). De kwaliteitskloof kan worden gehanteerd als (inverse)maatstaf voor de kwaliteit van de door een accountant geleverde diensten.

Naast de boven reeds genoemde kenmerken (in casu relativiteit, subjectiviteit en dynamiek) bevat het kwaliteitsbegrip een vierde kenmerk: multidimensionaliteit (Lemmink, 1991). Kwaliteit is opgebouwd uit verschillende elementen. Deze elementen kunnen elkaar soms onderling beïnvloeden. In navolging van Grönroos (1978) heeft Dassen (1995; 1997) de kwaliteitselementen opgesplitst in twee categorieën:

- technische kwaliteitselementen van de accountantscontrole;

- enfunctionele kwaliteitselementen van de accountantscontrole.

Opgemerkt zij dat de prijs van de accountantscontrole niet tot de kwaliteit mag worden gerekend. De prijs kan echter wel de verwachtingen beïnvloeden en daarmee de kwaliteitsperceptie.

De technische kwaliteitselementen hebben hoofdzakelijk betrekking op de intrinsieke facetten van de controle. Zaken als onder meer onafhankelijkheid en deugdelijke grondslag worden als technische kwaliteitsaspecten aangemerkt. De literatuur over de kwaliteit van accountantsdiensten heeft zich tot nu toe voornamelijk met deze vaktechnische zaken beziggehouden (zie ook Limperg Instituut, 1987 en NIVRA, 1992).

Zowel Leeflang et al. (1995) als Dassen (1995) hebben daarentegen tevens functionele kwaliteitselementen voor accountants onderzocht. Deze elementen zijn extrinsiek van aard en daarmee gerelateerd aan de wijze waarop de dienst wordt verleend (zie ook Dassen, 1997). Voor beide onderzoeken heeft het SER VQUALmodel (Parasuraman et al., 1986) als uitgangspunt gediend. Gezien het specifieke karakter van de markt voor accountantsdiensten heeft Dassen (1995) een aantal items toegevoegd aan de generieke structuur van Parasuraman c.s. De toegevoegde items omvatten onder meer het signaleren van attentiepunten op het gebied van de jaarverslaggeving, de organisatie van de informatievoorziening, de ondernemingsfinanciering en de algemene bedrijfsvoering. Deze items zou men grosso modo kunnen scharen onder de factor 'Partner in Business'. De adviezen die hieruit rollen zijn in principe 'bijproducten' van de accountantscontrole en worden derhalve door 
Dassen (1995) tot het functionele kwaliteitsbegrip gerekend.

\section{De kwaliteitskloof}

Verscheidene oorzaken kunnen aan de hiervoor genoemde kwaliteitskloof ten grondslag liggen. Op basis van deze te onderscheiden oorzaken zijn sub-kloven aan te wijzen. Vanuit het oogpunt van $k$ waliteitsbeheersing vraagt elke sub-kloof om een fundamenteel andere beheersingsmethodiek.

Eerder onderkende ik reeds een kwaliteitskloof in ruime zin en een verwachtingskloof. De verwachtingskloof is verder op te delen in een communicatie-kloof en een prestatie-kloof (zie ook Berendsen, 1991). Ook Porter (1991) onderscheidt een kloof veroorzalakt door irreële verwachtingen ('reasonableness gap') en een 'performance gap'. De latstgenoemde kloof deelt zij vervolgens op in een "deficient performance gap' en een 'deficient standards gap".

De communicatie-kloof is het verschil tussen wat het maatschappelijk verkeer respectievelijk de opdrachtgevers van de accountant daadwerkelijk verwachten en wat men redelijkerwijs van een (goede) accountant mag verwachten. De kern van de kloof wordt derhalve gevormd door irreële verwachtingen. Berendsen (1991) schrijft de communicatie-kloof toe ain het uit elkaar groeien van openbare accountant en maatschappij wallrdoor de grenzen van zijn kennen en kunnen onvoldoende duidelijk zijn. De prestatie-kloof heeft daarentegen betrekking op het (in de ogen van de afnemers) tekortschieten van de accountant bij de uitvoering van zijn opdracht. Met andere woorden: het verschil tussen de perceptie van de geleverde prestaties en wat men redelijkerwijs zou mogen verwachten van de prestaties van een accountant. De communicatie-kloof is hiemee hoofdzakelijk een probleem van informatieasymmetrie en onvolledige kennisoverdracht; de prestatie-kloof is meer een operationeel probleem voor de beroepsgroep.

Parasuraman et al. (1985) hebben een alternatieve indeling gemaakt voor de kwaliteitskloven van diensten in het algemeen. Dit zogenaamde gap-model of SERVQUAL-model onderscheidt hoofdzakelijk verscheidene communicatiekloven (waaronder communicatiestoornissen binnen de organisatie van de dienstverlener). Een prestatie- klool wordt echter niet expliciet onderscheiden; het onvoldoende presteren wordt in deze optiek leitelijk (impliciet) toegeschreven aan interne communicatieproblemen.

In feite kan zich naasi (of binnen) de verwachtingsk lool nog een kloof voordoen: een verschil ussen de door de accountant feitelijk geleverde prestatie en de door de afnemers gepercipiecerde prestatie ('perception bias', EO). Dit verschil tussen feitelijke kwaliteit en kwaliteitsperceptie is ook een soort communicatie-kloof. Voor het maatschappelijk verkeer (en de cliënt) is het vaak moeilijk (als niet onmogelijk) om de feitelijke prestatie in te schatten. Dit geldt zeker voor wat betreft de technische kwaliteitsfacetten. Een bekend voorbeeld van de hier bedoelde kloof is het onderscheid tussen "independence in fact" en "independence in appearance".

He1 probleem dat accountants niet alan de verwachtingen van het maatschappelijk verkeer dreigen te voldoen is niet nieuw. Reeds in 1926 schonk Limperg in zijn Le'er van het gewekte vertrouwen aandacht aan dit probleem (Limperg. 1933). De ernst van gebrekkig functionerende accountants maakle Limperg duidelijk door de normaticve kern van zijn vertrouwensleer op het probleem van de verwachtingskloof te richten. ${ }^{3}$ Expliciet duidde Limperg op de twee mogelijke oorzaken van de dissonantie tussen het gestelde vertrouwen en de vervulling van de functie: ' $\mathrm{Er}$ kan zijn een overdrev'll vertrouwen en een tekortkoming in de vervulling van de functie' (Limperg, 1993; p. 234).

Bij mijn weten is er tot op heden binnen de verwachtingskloofliteratuur geen aandacht geschonken atan het reële deel van de (onbevredigde) wensen dat de grens van de redelijke verwachtingen te boven galat. Aldus richt men zich voornamelijk op het huidige dienstenpakket van de accountants en de huidige inhoud van deze diensten. Er bestaat echter een kloof tussen wat als reële verwachting wordt alangemerkt en wat de wensen van de afnemers van de accountantsdiensten zijn. Deze kloof zou ik als de kansen-kloof ('opportunities gap') willen aanduiden. Meer oog voor deze kansen-kloof zal naar mijn mening op de lange termijn crucialal worden. Immers in de onbevredigde wensen van de afnemers ligt een kans tot succes. door het volgen van een marketingconceptie in plaats van een producl- of ver- 
koopgeoriënteerde fïlosofie (zie ook Leeflang et al.. NIVRA-geschrift 37. 1985). Het onderzoeken van de wensen geeft inzich in mogelijkheden voor de exploitatie van nieuwe (bij)producten en/of wijziging van de inhoud van de huidige diensten. Marktonderzoek en een goede communicatie met het publiek verkeer is hierbij een "conditio sine quat non". Gezien het belang van de maatschappelijke verantwoordelijkheid van de accountant is ten aanzien van de wensen ook cen tweedeling noodzakelijk in reële wensen en irreële wensen. De irreële wensen zullen een onbevredigde fictic blijven. Een voorbeeld hiervan zou kunnen zijn het adviseren van de cliënt in het ontduiken van belasting. De rest-kloof die de accountant vanuit zijn mattschappelijke verantwoordelijkheid uileindelijk nooit zal mogen dichten zal ik als fictic-klorf alanduiden. Het optimale aspiratieniveau voor de prestaties van de accountant zal zich derlalve bewegen lussen de grenzen van de reële verwachtingen en de reële wensen. Het exacle optimum zal in de praktijk worden bepaald in afstemming met het gevoerde prijsbeleid.

Figuur 1 geeft als voorbeeld een samenvaltend overzicht van de voor dit artikel relevante componenten van de kwaliteitsklool. ${ }^{4}$ De kwaliteitsklool in perceptie stat hierbij centraal. Aangezien een aantal kloven bepalalde grenspunten gemeen hebben ontstaat er een indirecte relatie tussen de omvang van de diverse kloven. Zo zal in het voorbeeld zowel de kansen-kloof als de communicalie-kloof in relatieve omvang afnemen zodra het niveau van de reële verwachtingen op een hoger niveau komt te liggen. De kinsen-kloof en de perceptie-kloof zijn dalarentegen onathankelijk alangezien zij conceptueel geen gemeenschappelijk grenspunt vertonen.

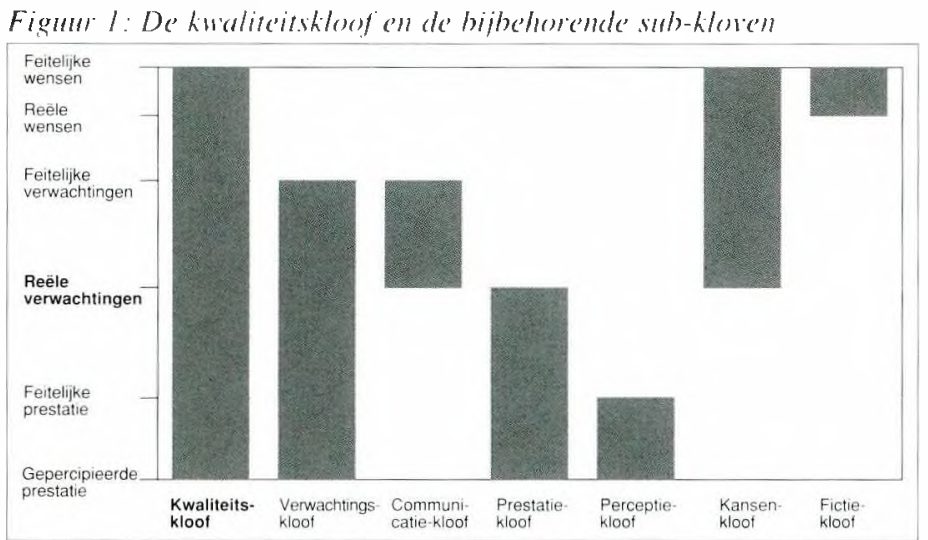

\section{+ (On)redelijke verwachtingen}

Diverse onderzocken zijn het laatste decennium verricht naar de verwachtingen die bij het maatschappelijk verkeer leven ten aanzien van de functie van de openbare accountant. In het algemeen kan worden gesteld dat op bepaalde punten de verwachtingen de grenzen van de redelijkheid in meerdere of mindere mate te boven gaan.

De verwachtingen die bestaan ten aanzien van een goede accountant betreffen vele laken. Van de 30) taken die Porter ( 1991 ) onderzocht bleken er 28 tot de anwezige verwachtingen te behoren; van deze 28 laken waren volgens het onderzock malar liefst 11 als onredelijk alan te merken.

Het Limperg Instituut publiceerde in 1987 de resultaten van een onderzoek naar de opvaltingen die in Nederland heersen ten alanzien van de functie van accountants en de betekenis van de accountantsverklaring. Het instituut onderzocht ook expliciet een aantal irreële verwachtingen ten aanzien van accountants en de accountantsverk litring. Opvallend was het relatief groot aantal respondenten dat bepaalde (vanuit vaktechnisch oogpunt) onredelijke verwachtingen koesterde. Tot deze verwachtingen behoorde onder meer de verwachting dat een goedkeurende verklaring inhoudt dat de verant woording volledig foutvrij is en dat deze impliceert dilt het voortbestian valn de onderneming is gewalarborgd. Uit recenter Amerikians onderzoek naar de verwachte mate van zekerheid. die een accountant geeft voor wat betreft het ontdekken van materiële (onopzettelijke) fouten dan wel materiële fraude. bleek dat voor wat betreft het ontdekken van fouten bij ruim $47 \%$ van de onderzochte aandeelhouders de verwachting bestond dat de accountant volledige zekerheid verschaft. Voor het ontdekken valn matcriële fraude bleek dit maar liefst $71 \%(!)$ te zijn (zie Epstein et al.. 1994). Naar blijkt is. naast de tolerantie door toepassing van het materialiteitsbeginsel. de beperking in de zckerheid uit hoofde van het aanvaard accountantscontrolerisico en de rol van hel axiomatisch voorbehoud niel voldoende duidelijk voor buitenstainders.

Mede als gevolg van de toenemende sociale verantwoordelijkheid van de te controleren huishoudingen zijn de verwachtingen van het maalschappelijk verkeer len alanzien van accountants stijgende. Natast de bovengenoemde (vak- 
technisch irreële) verwachtingen heersen er verder onder meer verwachtingen die zich in het grensgebied van de (on)redelijkheid begeven. De taken zelf staan hierbij niet zozeer ter discussie doch meer de vraag hoever de accountant moet gaan bij de uitvoering van deze taken en de mate waarin hij daarbij verantwoordelijkheid draagt. Tot deze verwachtingen kunnen de relatief recente uitbreidingen van de traditionele accountantstaken worden gerekend zoals de rol van de accountant bij het ontdekken en voorkomen van fraude, de aandacht van de accountant voor de betrouwbaarheid van hel geautomatiseerd informatiesysteem in het kader van de Wet Computercriminaliteit, het in de accountantsverklaring tot uitdrukking brengen van de gevolgen van onwettig handelen, het tijdig attenderen op continuïteitsgevaar: de werkzaamheden inzake 'Corporate Governance', en het melden aan de bedrijfsleiding van gebreken in de interne organisatie. Ten aanzien van dit laatste punt blijkt er behoefte te zijn aan meer aandacht van de accountant voor het 'internal control'-systeem van de organisatie. Zo getuigt de uitgebreide aandacht voor de COSO- en Cadburyrapporten.

Vanuit verschillende gezichtspunten komen normen tot stand voor wat een goede accountant zou moeten leveren. NIVRA-geschrift 59 geeft in dit kader een goede beschouwing over de conceptuele achtergrond van de totstandkoming van normen voor accountants (Schilder et al., 1991). In de praktijk leidt een complex van processen waaronder wetgeving, beroepsreglementering, marktonderzoek en theorievorming - tot een veelvoud van normen en opvattingen over redelijkheid waarmee accountants worden geconfronteerd. Gesteld moet echter worden dat moeilijk eenduidig is te bepalen of een bepaalde verwachting nu als redelijk of onredelijk kan worden bestempeld. Dit impliceert dat de omvang van de prestatie- en communicatie-kloof moeilijk is vast te stellen.

De redelijkheidsgedachte beweegt zich binnen een interval dat in een continuüm overloopt in onredelijkheid. Daarnaast is en blijft redelijkheid, net als kwaliteit, een relatief, dynamisch en tot op zekere hoogte subjectief begrip. Met deze eigenschappen zal ook rekening moeten worden gehouden bij de interpretatie van figuur 1 .

Het op ethische en economische gronden bepalen van grenzen (of beter: grensgebieden) tussen redelijke en onredelijke verwachtingen is in mijn optiek moeilijker voor accountants dan voor diverse andere dienstverleners. De markt voor accountantscontrole onderscheidt zich zoals bekend immers door het feit dat de dienst simultaan wordt afgenomen door meerdere afnemers met verscheidene, vaak tegenstrijdige belangen. Vanuit de agency-theorie wordt gesteld dat de openbare accountant als agent van (minimaal) twee principalen optreedt (Dassen, 1989).

\section{Het dichten van kwaliteitskloven}

Uit het bovenstaande moge blijken dat kwaliteitsbeheersing van accountantsdiensten in de praktijk een diffuus probleem kan vormen. Ik wees er reeds op dat elke sub-kloof een andere wijze van beheersing eist; verschillende oorzaken vragen om andere oplossingen. Binnen de literatuur op het gebied van accountantsk waliteit en verwachtingskloven worden thans diverse mogelijkheden aangedragen voor de beheersing van kwaliteitsdiscrepanties. Ik zal kort op enkele mogelijkheden ingaan. Een aantal van deze opties vinden in de praktijk reeds hun weerslag.

\section{Communicatie-kloof}

Zoals figuur 1 weergeeft, vormen de reële verwachtingen de spil van het kwaliteitsbeheersingsraamwerk. Teneinde een betere conceptie te krijgen van wat nu wel en niet als reëel moet worden beschouwd is een permanente discussie binnen de beroepsgroep, maar ook tussen accountants en het maatschappelijke verkeer noodzakelijk. Laatstgenoemde externe communicatie is inherent aan de publieke functie. Een snelle internalisering van de uitkomsten van deze discussies in de richtlijnen van de beroepsgroep zullen ertoe leiden dat deze richtlijnen beter aansluiten bij de behoeften van de samenleving. Door de dynamiek in de waarden en behoeften zal dit een continu aanpassingsproces voor de regels en richtlijnen impliceren. Kollenburg geeft de essentiële invloed van de afnemers schematisch weer (zie Krouwer, 1993). Uit zijn schema blijkt dat door de samenspraak met de gebruikers de productnormen (in casu reële verwachtingen, EO) kunnen worden bepaald. Waar het belang van overleg met het publiek verkeer ter sprake komt wordt ook wel gewezen op het nut van het instellen van een geformaliseerde structuur 
middels een platform. De Commissie Blokdijk (NIVRA. 1993) spreckl in dic zin van een Maatschappelijke Adviesraad. Berendsen (1991) stelt voor een 'Raad van Overleg inzake Accountantswerkzaamheden' in te vocren, die relatief autonoom moet opereren.

Ook goed overleg tussen de individuele accountants(kantoren) en de alnemers van hun diensten wordı voor beide groepen als belangrijk beschouwd. Accountants krijgen een betere visie op wat van hun wordt verwacht en kunnen inspringen op de mate waarin deze verwachtingen reëcl zijn. Deze kennis is tevens waardevol voor het dichten van de prestatie-kloof. De afnemers hrijgen daarnaast een beter begrip van de rol en werkzalamheden van de accountant. en daarmee van wal ze redelijkerwijs van hem zouden mogen verwachten. Het informeren van én overleggen met de afnemers is dararmee de sleutel tot het overbruggen van de communicatic-kloof. Duidelijkheid in de uitingen (waaronder de verschillende soorten verklaringen) van de accountant is in dit kader eveneens van belang. De Commissie Blokdijk heeft gewezen op de noodzalak tot voorlichting over de betekenis van het axiomatisch voorbehoud ter bestrijding van de verwachtingskloof (NIVRA. 1992).

\section{Prestatie-kloof}

Ten aanzien van de matregelen die kunnen worden genomen ler beheersing van het prestatieniveau van de openbare accountant is eveneens een onderscheid te maken Iussen matregelen die collectief (door onder meer de beroepsorganisatie) kunnen worden genomen en maatregelen die door de individuele accountants(kantoren) kunnen worden genomen. Onderstiande maatregelen zijn grotendeels preventief van alard, walar nodig. alangevuld met enkele repressieve maatregelen. Voorkomen is immers beter dan genezen.

Voor wat betrefi de beroepsorganisatie worden reeds de nodige maatregelen genomen waaronder het geven van 'quality control standards'. het geven van verdere richtlijnen ter bepaling van algemeen alanvaarde controlegrondslagen (GAAS), het verzorgen van permanente educatie en vakpublicaties, de uitvaardiging van gedragsen beroepsregels en als noodzakelijke aanvulling hierop de zorg voor tuchtrechtspralak. Matatregelen die de beroepsorganisatie kan nemen zijn het instellen van een 'peer review'-regeling (in Nederland effectief sinds 1 januari 1997), het frequent (publiekelijk) onderzoeken van de $h$ waliteit van afgegeven accountantsverklaringen door een commissie van de beroepsorganisatie (dan wel uitbreiding van de laken van de COPA), het gebruik van een keurmerk voor samenwerkingsverbanden (met een beperkte geldigheids(luur) en een periodieke toetsing van de vaktechnische kennis van haar leden (zie ook NIVRA. 1992: pp. 27-28). Als uitvloeisel van het Actieplan 1995 'Kuraliteit. innovatie en duidelijkheid" zijn door het Koninklijk NIVRA nieuwe kwaliteitsvoorschriften opgesteld en in ontwikkeling.

In RAC 220 (Koninklijke NIVRA, 1996) geelt de beroepsgroep adnwijzingen voor kwaliteitsbeheersingsmaatregelen voor individuele accountants(kantoren). Van belang is onder meer een strikte interne $k$ waliteitsbewaking en het voeren van een actiel en evenwichtig personeelsen opleidingsbeleid. Uit de Anglo-Saksische wereld komen verder suggesties als toepassing van 'partner rotation" voor langdurig doorlopende controleopdrachten. Ten slotte zou men door een scheiding van functies binnen het accountantskantoor kunnen waken voor ernstig collisiegevaar. Er zijn immers grenzen aan het 'full service'-concept (NIVRA. 1992). Frappant is in dit kader de strategische keuze valn een alantal grote accountantskantoren om toe te werken naar multidisciplinair samengestelde controleteams.

\section{Kansen-kloof}

Teneinde de kansen-kloof te dichten kunnen accountantskantoren vruchibalar gebruik maken van goed marktonderzoek voor de inventarisatie van onbevredigde wensen. waaronder de vraag naar nieuwe en of verbeterde (bij)producten. Zoals eerder gesteld zal de accountant echter niet aan alle wensen tegemoet kunnen/mogen komen. Middels het communiceren nalar cliënten en malatschappelijk verkeer van de vertrouwensrol en ethiek verbonden aan de openbare functie zullen irreële wensen en dararmee de fictie-kloof beperkt kunnen blijven. In die zin is ook de fictie-kloof een soorl communicatie-kloof. Naar mijn mening zal met name een gezonde marktwerking "automatisch ' leiden tot exploitatie van de kansen-kloof. De veranderde marktsituatie voor accountantsdiensten (van een aanbiedersmarkl nalar een vragersmarkt) makt een lange-termijn proactief 
beleid immers noodzakelijk wil men binnen deze markt overleven ('survival of the fitting').

\section{Empirische analyse}

Diverse onderzoeken zijn in de afgelopen jaren verricht naar het voorkomen en de aard van kwaliteitskloven (zie ook Porter, 1991; CICA, 1988; Epstein et al., 1994 en Limperg Instituut, 1987). Deze onderzoeken hebben zich in essentie beperkt tot de verwachtingskloof. Dassen (1995) heeft een onderzoek gedaan naar de kwaliteitsperceptie ten aanzien van het functioneren van accountants bij cliënten en bankiers in het kader van controleopdrachten. De bankiers vertegenwoordigen hierbij een belangrijke groep van externe belanghebbenden. Dassen onderzocht zowel technische kwaliteitselementen als functionele kwaliteitselementen. Het onderzoek richt zich op de vraag welke van deze kwaliteitsfactoren de totale, algemene kwaliteitsindruk bepalen en op de vraag welke kenmerken van specifieke controle-opdrachten (zoals bijvoorbeeld de omvang van de cliënt ten opzichte van de omvang van het accountantskantoor) de perceptie van het prestatieniveau beïnvloeden (zie ook Dassen, 1997). Bij deze vragen staat steeds een vergelijking tussen de uitkomsten voor bankiers en de uitkomsten voor cliënten centraal.

Aangezien kwaliteit de inverse vormt van de kwaliteitskloof is het mogelijk geweest op basis van de door Dassen verzamelde onderzoeksdata een empirische analyse uit te voeren ter toetsing van het bestaan en de omvang van (technische en functionele) kwaliteitskloven. In de schriftelijke enquête werden gesloten vragen gesteld over wat in de ogen van de respondent de ideale accountant behoort te doen en over het prestatieniveau van de huidige accountant op deze punten. Dit betekent dat, in termen van het conceptueel kwaliteitskloofmodel zoals beschreven in paragraaf 2 en 3 , gegevens zijn verzameld over het niveau van de wensen van de afnemers van accountantsdiensten en over het niveau van de gepercipieerde prestatie. Aldus kan een beeld worden gevormd van de kwaliteitskloof in ruime zin zoals weergegeven in figuur 1 . Zoals reeds in paragraaf 3 gesteld, is het bepalen van de feitelijke prestatie en zo de perceptie-kloof praktisch moeilijk. Dit is een algemeen kenmerk van diensten. Derhalve is de gepercipieerde prestatie hier (slechts) als surrogaat voor de feitelijke prestatie te beschouwen.
Voor de beschrijving van de onderzoeksopzet verwijs ik naar het artikel van Dassen in het voorgaande nummer van het MAB. ${ }^{5}$ Op basis van de enquêtegegevens heb ik de omvang van de kwaliteitskloof per onderzocht kwaliteitselement bepaald. Hierbij is een 7-punts Likert-schaal gehanteerd. De statistische uitkomsten van deze analyse zijn opgenomen in de bijlage (zie pp. 136138). Teneinde een betere notie te krijgen van de omvang van de kloof zijn de kloven niet alleen absoluut bepaald doch ook als percentage van het gewenste prestatieniveau. Ik zal dit verder aanduiden als de relatieve kwaliteitskloof. Geen vragen werden in de enquête gesteld over de verwachtingen ten aanzien van de huidige accountant zodat de verwachtingskloof sec niet kan worden bepaald. Verder is hier (gezien de eerdere opmerkingen over de complexiteit van het redelijkheidsconcept) geen poging ondernomen om een redelijkheidsgrens te bepalen teneinde de prestatie- respectievelijk communicatie-kloof te meten. Nader onderzoek is voor deze facetten nodig. De statistische significantie van de berekende gemiddelde kwaliteitskloof is (apart voor bankiers en cliënten) bepaald middels een paarsgewijze t-test op het verschil tussen het gemiddeld gewenste niveau en het gemiddelde in perceptie geleverde niveau van de prestatie.

De uitkomsten van de tests resulteren in de volgende bevindingen:

- Ten aanzien van de technische kwaliteitselementen:

- Voor het merendeel van de elementen is er sprake van een zeer significante kwaliteitskloof (zelfs bij een betrouwbaarheidsniveau van 99\%); voor de bankiers zijn zelfs alle elementen significant. Onder deze significante kloven bevinden zich enkele die in hun relatieve omvang opvallen. Dit betreft ten eerste het ontdekken van 'harde' fouten in de verantwoording (circa $14 \%$ voor beide groepen) en het ontdekken van resultaatverschuivingen (cliënten 12\%; bankiers 13\%). Op basis hiervan dient de vraag zich aan of accountants de materialiteit niet te hoog inschatten en of de geleverde mate van zekerheid wel voldoet aan de wensen van de afnemers. De kloof ten aanzien van het ontdekken van fraude is bij bankiers relatief hoog (circa 12\%). Opvallend is verder het verschil tussen bankiers en cliënten in de relatieve kloven van enkele 
"meldings"-vragen (zoals het melden van fouten en hel melden van onwettig handelen in de accountantsverklaring). Als gevolg van de tegenstrijdige belangen tussen beide groepen zijn deze kloven bij bankiers structureel hoger. Zeer opmerkelijk blijft echter dat volgens de visie van de cliënten ten aanzien van het melden in de accountantsverklaring van harde fouten en resultaatverschuivingen (zijnde twee onafhankelijkheidselementen!) het prestatieniveau significant achler blijft bij de wensen.

Vooralsnog is er (naar mijn weten) geen audittheorie voor handen die dit curieuze verschijnsel kan verklaren.

- Bij de cliënten zijn overigens voor de andere onafhankelijkheidselementen de kwaliteitskloven niet significant. Dit betreft onder meer het in de accountantsverklaring wijzen op continuïteitsbedreigingen. Cliënten zijn waarschijnlijk bewust van de dreiging van een "selffulfilling prophecy'. Bij bankiers is op dit punt echter sprake van een zeer significante relatieve kwaliteitskloof valn circa 13\%. hetgeen verklaarbaar is vanuit hun financieringsrisico. Dc overige kwaliteitskloven die bij de cliënten bij een betrouwbaarheidsniveau van $95 \%$ niet significant zijn betreffen het melden van fraude in de accountantsverklaring. het melden van fraude bij de fiscus. het melden van geconstateerd onwettig handelen in de accoumlantsverklaring en het in de accountantsverklaring vermelden van tekortkomingen in de interne organisaltic. De cliënten hebben blijkbaar voor deze zaken geen behoefte aan een hogere onafhankelijkheid bij openbare accountants. Dit is in overeenstemming mel de verwachtingen op grond van de agency-theorie.

- De (relatieve) kwaliteitskloof is voor vrijwel alle elementen groter bij bankiers dan bij cliënten, dit ondanks de in het algemeen lagere gemiddelde perceptie van het prestatieniveau bij cliënten. Dit verschijnsel is toe te wijzen aan het feit dat de wensen van de bankiers gemiddeld steeds boven de wensen van de cliënten blijken te liggen (zie ook Dassen, 1996). Hieruit kan men concluderen dat de behoefte (dan wel de eisen die worden gesteld) aan accountantscontrole vanuit hel matschappelijk verkeer ('monitoring') sterker is dan de behoefte vanuit de gecontroleerde ondernemingen ('bonding'), hetgeen verenigbaar is met de vertrouwensfunctie van de accountant.
- Ten aanzien ran de functionele kwaliteitselementent:

- Ook voor wat betreft de functionele kwaliteit zijn de kloven bij beide groepen voor de meeste elementen significant. Bijzonder opvallend is de grote kloof ten aanzien van de kwaliteil van de nota-specificaties (43\%!). Deze bevinding strookt met eerder onderzoek waruit is gebleken dat er weinig tevredenheid heerst bij cliënten ten alanzien van de inzichtelijkheid van de declaraties (Dikstaal, 1992; Leeflang et al.. 1995). De overige kloven van relatief grote omvang betreffen tijdige levering (15\%), op tijd komen (11\%), weinig wisselende controleteams (10\%), signaleren van fiscale attentiepunten (11\%) en attentiepunten voor de ondernemingsfinanciering ( $16 \%$ ), regelmatig bespreken van bevindingen ( $11 \%$ ) en persoonlijke aandacht voor de cliënt ( $16 \%$ ).

- Enkelc kloven blijken níet significant te zijn. zodat men kan stellen dat de gepercipieerde $\mathrm{kwaliteil}$ voor deze elementen hoog is. Dit betreft onder meer voor beide groepen het verzorgd voorkomen van de accountant en zijn moderne technische uitrusting. Voor cliënten komt daar bij het signaleren van attentiepunten voor de algemene bedrijfsvoering, het nooit te druk hebben voor vragen en het voorop stellen van het belang van derden. Voor dit laatste element is de gemiddelde kloof zelfs negatief, doch niet significant. Dit zelfde geldt voor de hotfelijkheid en vriendelijkheid van de medewerkers. gezien vanuit het oogpunt van de bankiers.

- Zeer opvallend zijn de gevallen waarin er sprake is van een significant negatieve kloof; (lat wil zeggen de gevallen waarin de gepercipieerde prestatie gemiddeld bóven het gewenste niveau ligt. Aangezien het gaat om het ongev'enst overtreften van de behoeften is dit vanuit kwaliteitsoogpunt niet als positief aan tc merken. De elementen die een dergelijke significante negatieve kloof vertonen betreffen voor cliënten de hoffelijkheid en vriendelijkheid van de medewerkers en voor beide groepen de visuele almtrekkelijkheid van het gebouw van het accountantskantoor. Uiterlijk vertoon komt de $k$ waliteitsperceptie blijkbaar niet ten goede.

Uit het bovenstaande blijkt dat, voor wat betreft de onderzochte technische en functionele 
kwaliteitselementen. de gepercipieerde kwaliteitskloven per individueel element qua omvang in de meeste gevallen (zeer) significant zijn. Dit zegt echter nog niets over de emst van de kloven voor het tolale kwaliteitsoordeel over openbare accountants. In het onderzock werd de respondenten tevens gevraagd een totaloordecl over het functioneren van de accountant te geven. Dassen (1997) concludeert op basis van deze onderzoeksdata dat de respondenten gemiddeld een positiel totaaloordeel hebben (circa 5.4 op een 7-puntsschaal). Om inzicht te krijgen in de invloed van de diverse kwaliteitselementen op het lotaaloordeel heeft Dassen (1995; pp. 135-152). na factoranalyses, een regressievergelijking opgezet. In deze lineaire vergelijking is het totaaloordeel uitgedrukt als functie van de verschillende lunctionele en technische kwaliteitsfactoren. Deze exercitie geeft mede inzicht in de wegingsfactoren van de individuele $k$ waliteitsk loven voor de uiteindelijke (on)tevredenheid over openbare accountants. Een vergelijkbare alanpak wordt gevolgd in het onderzoek van Leeflang en Willenborg (1995). Het gemiddelde rapportcijler dat de accountant krijgt blijkt ook uit dit onderzoek vrij hoog te zijn; de prijs-kwaliteitsverhouding blijkı daarentegen de meeste zorg te vergen (Leeflang et al.. 1995: pp. 355-356). De onderzoekspopulatic is uitsluitend de afnemersgroep 'cliënten', warbij men zich heeft beperkt tot de meting valn het niveau van de gepercipieerde prestatie. In de analyse van Leeflang en Willenborg wordt uitgegaan van de vijf generieke groepen functionele kwaliteitsdimensies zoals deze door he SERVQUAL-model worden aangedragen. Dassen heeft daarentegen met behulp van factoranalyse de binnen zijn onderzoek relevante dimensies afzonderlijk bepaald. Dassen (1995; p. 146) concludeert dat voor zowel cliënten als (merk waardig genoeg) bankiers functionele kwaliteitselementen belangrijker zijn voor de tevredenheid over de accountant dan technische elementen. Sleutelfactoren hierbij zijn commmni(anie (zowel intern als extern) en professionaliteit. Deze factoren bleken reeds eerder in dit artikel van belang voor de beheersing van de communicatie- respectievclijk prestatie-kloof.

Ook uit het onderzoek van het Limperg Instituut (1987) bleek het tolatialoordeel van het publiek verkeer met betrekking tot de algehele tevredenheid over de accountant in zijn controlefunctie "vrij positiel" te zijn: voor wat betreft de adviesfunctic was deze tevredenheid duidelijk lager. Dit laatste is consistent met de hierboven besproken kloof ten aanzien van hel signaleren van fiscale en financieringsattentiepunten. Het Limperg Instituut concludeerde eveneens dat de mate van de tevredenheid bij de respondenten over de praktijk ten aanzien van de kwaliteit van de jaarrekening, de preventic en het ontdekken van fraude. het tijdig melden van continuïteitsgevilar en het tijdig intern melden van gebreken in de interne organisalie vrij ernstig achterblijft bij de verwachtingen. De bevindingen van het Limperg Instituut ten aanzien van de verwachtingskloven zijn goed verenigbaar mel de empirische bevindingen in dit artikel. Buitenlandse onderzoeken geven eveneens bewijs voor hel bestaan van kwaliteitskloven (hoewel met name beperkt tot verwachtingskloven). Porter (1991) vond dal er bij 2.5 valn de 30 door haar onderzochte taken sprake was van een verwachtingskloof. Het onderzoek van het CICA (1988), ten slotte, geeft aan dat accountants een vrij hoog aanzien genicten bij het publiek: doch dat het vertrouwen dat in accountants is gesteld bijzonder fragiel is.

\section{Conclusie}

In dit artikel is een beschouwing gegeven over de kwaliteitsbeleving van cliënten en het publick verkeer ten aanzien van het functioneren van openbare accountants. Datarbij is de kwaliteitskloof (de mate waarin accountants niet alan de we'nsen van hun alinemers voldoen) centraal gesteld. Met behulp van empirische data, afkomstig van met name middelgrote cliënten en hun bankiers, is aangetoond dat bij het leeuwendeel van de onderzochte functionele en technische $k$ waliteitselementen sprake is van een zeer signilicante kwaliteitskloof. Dit betekent dat de prestaties voor deze elementen in de perceptie van de twee onderzochte afnemersgroepen achter blijven bij de wensen. Volgens het onderzoek van Dassen (1997) blijken de gepercipieerde prestaties soms zelfs beneden het alanviardbalar geachte niveau te blijven. Desalnicttemin blijkt uit diverse studies dat het totacloordeel over de accountant toch vrij positief is, hetgeen betekent dat de kwaliteitselementen waarvoor de kwaliteitskloof ernstig is gebleken uiteindelijk minder zwaar weegt in de algehele waardering van de accountant. Opgemerkt dient te worden dat hoewel de in dit artikel onderzochte facetten een groot deel van de kwaliteitselementen van accountantscontroles afdekken ze natuurlijk niet uitputtend 
zijn. Nader onderzoek naar de aard en het relatieve belang van de heersende kwaliteitskloven (en de daartoe behorende sub-kloven) en naar de effectiviteit van de verschillende beheersingsmethodieken is mijns inziens gewenst.

Bij het analyseren van de kwaliteitskloof blijkt één van de meest essentiële vragen te zijn: $W a t$ mogen de principalen nu redelijkerwijs van hun accountant verwachten? Deze vraag blijkt moeilijk te beantwoorden. Het invoeren van een fictieve 'verstandige leek' maakt het beantwoorden van deze vraag trouwens niet eenvoudiger. Bovendien verandert 'het antwoord' in de loop der tijd. De verwachtingen die heersen ten aanzien van accountants zijn in het algemeen hoog en lijken in bepaalde gevallen irreëel.

Het onderscheiden van sub-kloven is van belang daar, teneinde de kloven te kunnen dichten, iedere kloof een eigen aanpak vereist. Meer communiceren met de markt lijkt het belangrijkste credo te zijn dat in de verwachtingskloofliteratuur wordt aangedragen. Irreële verwachtingen bij het publiek dienen te worden weggenomen. Met name voor de lange termijn kunnen accountants marktpotentieel exploiteren door zich sterk te richten op het dichten van de, in dit artikel geïntroduceerde, kansen-kloof. Deze kloof wordt gevormd door het verschil tussen de wensen van de afnemers en wat vandaag de dag als redelijke verwachting geldt. Daarnaast zal de accountant zich op korte termijn moeten (blijven) inspannen om prestatie-kloven te vermijden. Verdergaande budgetdruk maakt dit geen eenvoudige taak. Voldoende deugdelijkheid en onafhankelijkheid blijven echter van vitaal belang. Voorkomen moet namelijk worden dat het vertrouwen van het maatschappelijk verkeer op het spel wordt gezet en dat claims tot de orde van de dag gaan behoren. Vertrouwen vormt immers de legitimatie voor het bestaan van de algemene accountantsfunctie.

\section{I T E R A T U U R}

Berendsen, J.G., (1991), Maatschappij, onderneming en accountant, Maandblad voor Accountancy en Bedrijfseconomie, april.

Blokdijk, J.H., (1989), Strategieën bij verwachtingskloven, Maandblad voor Accountancy en Bedriifseconomie, december.
Blokdijk, J.H., (1991), De verwachtingskloof: dempen of overbruggen?, Maandblad voor Accountancy en Bedriffseconomie, april.

Blokdijk, J.H., (1992), Denken over kwaliteit, De Accountant, april.

Blommaert, A.M.M., Olders, E.A.M., (1995), Renewing Accounting Systems, Triple Entry and Momentum Accounting: An Exploratory Study, Paper First Asian Pacific Interdisciplinary Research in Accounting Conference, Sydney.

Canadian Institute of Chartered Accountants (CICA), (1988), Report of the commision to study the publics expectations of audits, McDonald Commission.

Dassen, R.J.M., (1989), De Leer van het gewekte vertrouwen: Agency avant la lettre?, Maandblad voor Accountancy en Bedrijfseconomie, september.

Dassen, R.J.M. (1995), Audit Quality: An empirical study of the attributes and determinants of audit quality perceptions, proefschrift Rijksuniversiteit Limburg.

Dassen, R.J.M., (1997), Kwaliteit van accountantsdiensten: de markt aan het woord, Maandblad voor Accountancy en Bedriffseconomie, januari/februari.

Dikstaal, N., (1992), Profiteer nu van concurrerende accountants, Rendement, december.

Dubbeld, C., (1995), NIVRA-Kwaliteitsproject, De Accountant, oktober.

Epstein, M.J., Geiger, M.A., (1994), Investor views of audit assurance: Recent evidence of the audit expectation gap, Journal of Accountancy, januari.

Grönroos, C., (1978), A service-oriented approach to marketing of services, European Journal of Marketing, 8.

Koninklijk NIVRA, (1996), Richtliinen voor de Accountantscontrole.

Krouwer, R.P., (1993), Impressie van VERA-sessie 'Kwaliteit', De Accountant, maart.

Limperg jr, Th., (1933), De functie van de accountant en de leer van het gewekte vertrouwen, vifftig jaar MAB deel 2.

Limperg Instituut, (1987), Opvattingen over Accountants, Amsterdam.

Leeflang, P.S.H., Van Keep, A., Meer, R. van der, (1985), Marketing in relatie tot de accountant, NIVRA-geschrift 37.

Leeflang, P.S.H., Boxem, G., Van Dijk, J.A., (1992), De markt voor accountantsdiensten in Nederland (deel 1), Maandblad voor Accountancy en Bedriffseconomie, maart.

Leeflang, P.S.H., Willenborg, G.B.W., (1995), Het meten van kwaliteit van de accountantscontrole, Maandblad voor Accountancy en Bedriffseconomie, juni.

Lemmink, J.G.A.M., (1991), Kwaliteitsconcurrentie tussen ondernemingen, proefschrift Rijksuniversiteit Limburg.

NIVRA, (1992), Kwaliteit: een integrale conceptie voor de kwaliteitsbevordering van dienstverlening door accountants, discussienota commissie Blokdijk, mei. 
Olders, E.A.M., (1995), De toepassing van dimensie-analyse op financieel-administratieve systemen, Maandblad voor Accountancy en Bedriffseconomie, juli/augustus.

Parasuraman, A., Zeithaml, V.A., Berry, L.L., (1985), A conceptual model of service quality and its implications for future research, Journal of Marketing, herfst.

Parasuraman, A., Zeithaml, V.A., Berry, L.L., (1986), SERVQUAL: A multiple-item scale for measuring customer perceptions of service quality, Marketing Science Institute, augustus.

Porter, B.A., (1991), An empirical study of the audit expectation-performance gap, paper EAA congres Maastricht, april.

Schilder, A., Poel J.H.R. van de, (1991), Normen voor Accountants, NIVRA-geschrift 59.

Van Zutphen, L.C., (1993), Het COSO-studierapport, Maandblad voor Accountancy en Bedriffseconomie, mei.

\section{N O T E N}

1 Met dank aan Prof. Dr. R. Dassen RA voor het mij ter beschikking stellen van zijn onderzoeksgegevens.
2 De Commissie Blokdijk geeft in een discussienota (NIVRA, 1992; p. 5) aan dat de hoogste vorm van kwaliteit is 'het overtreffen van de verwachtingen van de afnemer'. Het overtreffen van de verwachtingen kan echter in bepaalde gevallen ongewenst zijn en derhalve leiden tot een verlaging van de gepercipeerde kwaliteit (bijvoorbeeld té vriendelijke kledingverkopers). Dit staat ook wel bekend als een 'classic ideal point'-situatie (zie ook Dassen, 1995).

3 Limperg sprak niet expliciet van het begrip 'verwachtingskloof'.

4 Opgemerkt zij dat de verschillende prestatieniveaus (grenspunten) binnen deze figuur willekeurig zijn gekozen. Derhalve zijn ook de omvang en richting van de getoonde kloven willekeurig en niet als indicatief voor de praktijk bedoeld.

5 Voor de exacte inhoud van de gestelde vragen en gedetailleerdere gegevens over de verzamelde onderzoeksdata verwijs ik naar het proefschrift van Dassen (1995).

6 Aangezien het voor bankiers op sommige punten moeilijk is een oordeel te vellen over functionele kwaliteitselementen richt ik mij hier voornamelijk op de cliënten.

\section{Bijlage: Statistische uitkomsten van empirisch onderzoek}

Technische kwaliteitselementen

\begin{tabular}{|c|c|c|c|c|c|}
\hline Kwaliteitselement & $\mathbf{C} / \mathbf{B}$ & $\mathbf{W}$ & $\mathbf{W} \cdot \mathbf{P}$ & $(\mathbf{W}-\mathbf{P}) / \mathbf{W}$ & p-waarde ${ }^{*}$ \\
\hline \multirow[t]{2}{*}{ Ontdekken (harde) onjuistheden } & $\mathrm{C}$ & 5.89 & 0.80 & 13.58 & 0.00 \\
\hline & B & 6.45 & 0.89 & 13.79 & 0.00 \\
\hline \multirow[t]{2}{*}{ Melden (harde) onjuistheden } & $\mathrm{C}$ & 5.93 & 0.41 & 6.91 & 0.00 \\
\hline & $\mathrm{B}$ & 6.52 & 0.87 & 13.34 & 0.00 \\
\hline \multirow{2}{*}{ Ontdekken resultaatverschuivingen } & $\mathrm{C}$ & 5.46 & 0.65 & 11.90 & 0.00 \\
\hline & $\mathrm{B}$ & 6.46 & 0.86 & 13.31 & 0.00 \\
\hline \multirow{2}{*}{ Melden resultaatverschuivingen } & C & 5.34 & 0.48 & 8.99 & 0.00 \\
\hline & $\mathrm{B}$ & 6.42 & 0.85 & 13.24 & 0.00 \\
\hline \multirow[t]{2}{*}{ Ontdekken ernstige continuitteitsbedreigingen } & $\mathrm{C}$ & 6.36 & 0.58 & 9.12 & 0.00 \\
\hline & $\mathrm{B}$ & 6.83 & 0.79 & 11.57 & 0.00 \\
\hline \multirow[t]{2}{*}{ In verklaring wijzen op continuïteitsbedreigingen } & $\mathrm{C}$ & 5.07 & 0.11 & 2.17 & 0.21 \\
\hline & $\mathrm{B}$ & 6.37 & 0.83 & 13.03 & 0.00 \\
\hline \multirow[t]{2}{*}{ Ontdekken tekortkomingen in interne organisatie (IO) } & $\mathrm{C}$ & 5.31 & 0.45 & 8.47 & 0.00 \\
\hline & $\mathrm{B}$ & 5.96 & 0.39 & 6.54 & 0.00 \\
\hline \multirow[t]{2}{*}{ In verklaring wijzen op tekortkomingen in IO } & $\mathrm{C}$ & 4.60 & 0.27 & 5.87 & 0.07 \\
\hline & $\mathrm{B}$ & 6.01 & 0.64 & 10.65 & 0.00 \\
\hline \multirow[t]{2}{*}{ Ontdekken van fraude } & $\mathrm{C}$ & 6.14 & 0.55 & 8.96 & 0.00 \\
\hline & $\mathrm{B}$ & 6.67 & 0.81 & 12.14 & 0.00 \\
\hline \multirow[t]{2}{*}{ Melden fraude in verklaring } & $\mathrm{C}$ & 4.52 & 0.11 & 2.43 & 0.21 \\
\hline & $\mathrm{B}$ & 5.53 & 0.43 & 7.78 & 0.00 \\
\hline
\end{tabular}


Technische kualiteitselementen (vervolg)

\begin{tabular}{|l|c|c|c|c|c|}
\hline Kwaliteitselement & C/B & W & W-P & (W-P)/W & p-waarde* $^{*}$ \\
\hline Melden fraude bij fiscus & $\mathrm{C}$ & 4.27 & 0.09 & 2.11 & 0.27 \\
\cline { 2 - 6 } & $\mathrm{B}$ & 5.15 & 0.40 & 7.77 & 0.01 \\
\hline Ontdekken onwettig handelen & $\mathrm{C}$ & 4.58 & 0.48 & 10.48 & 0.00 \\
\hline Melden onwettig handelen in verklaring & $\mathrm{B}$ & 5.27 & 0.51 & 9.68 & 0.00 \\
\hline & $\mathrm{C}$ & 4.78 & 0.09 & 1.88 & 0.20 \\
\cline { 2 - 6 } & B & 5.55 & 0.56 & 10.09 & 0.00 \\
\hline
\end{tabular}

Functionele kwaliteitselementen

\begin{tabular}{|c|c|c|c|c|c|}
\hline Kwaliteitselement & $\mathbf{C} / \mathbf{B}$ & $\mathbf{W}$ & $\mathbf{W}-\mathbf{P}$ & $(\mathbf{W}-\mathbf{P}) / \mathbf{W}$ & p-waarde* \\
\hline \multirow[t]{2}{*}{ Signaleren fiscale attentiepunten } & $\mathrm{C}$ & 6.27 & 0.70 & 11.16 & 0.00 \\
\hline & $\mathrm{B}$ & 6.47 & 0.65 & 10.05 & 0.00 \\
\hline \multirow[t]{2}{*}{ Signaleren attentiepunten m.b.t. de jaarverslaggeving } & $\mathrm{C}$ & 6.42 & 0.50 & 7.79 & 0.00 \\
\hline & $\mathrm{B}$ & 6.56 & 0.63 & 9.60 & 0.00 \\
\hline \multirow[t]{2}{*}{ Signaleren attentiepunten m.b.t. ondernemingsfinanciering } & $\mathrm{C}$ & 5.87 & 0.94 & 16.01 & 0.00 \\
\hline & B & 6.32 & 0.90 & 14.24 & 0.00 \\
\hline \multirow[t]{2}{*}{ Signaleren attentiepunten m.b.t. organisatie en informatievoorziening } & $\mathrm{C}$ & 5.66 & 0.42 & 7.42 & 0.01 \\
\hline & B & 6.16 & 0.53 & 8.60 & 0.00 \\
\hline \multirow[t]{2}{*}{ Signaleren attentiepunten m.b.t. de algemene bedrijfsvoering } & $\mathrm{C}$ & 5.11 & 0.18 & 3.52 & 0.14 \\
\hline & $\mathrm{B}$ & 5.91 & 0.35 & 5.92 & 0.00 \\
\hline \multirow[t]{2}{*}{ Verzorgd uiterlijk } & $\mathrm{C}$ & 5.87 & -0.09 & -1.53 & 0.23 \\
\hline & $\mathrm{B}$ & 6.08 & 0.29 & 4.77 & 0.06 \\
\hline \multirow[t]{2}{*}{ Moderne technische uitrusting } & $\mathrm{C}$ & 5.83 & 0.20 & 3.43 & 0.11 \\
\hline & $\mathrm{B}$ & 6.36 & 0.32 & 5.03 & 0.00 \\
\hline \multirow[t]{2}{*}{ Verzorgde rapportage en correspondentie } & $\mathrm{C}$ & 6.42 & 0.20 & 3.12 & 0.02 \\
\hline & $\mathrm{B}$ & 6.57 & 0.49 & 7.46 & 0.00 \\
\hline \multirow[t]{2}{*}{ Visueel aantrekkelijk gebouw } & $\mathrm{C}$ & 4.27 & $-1.50(!)$ & -35.13 & 0.00 \\
\hline & $\mathrm{B}$ & 4.76 & $-0.83(!)$ & -17.44 & 0.00 \\
\hline \multirow[t]{2}{*}{ Tijdige levering, conform afspraak } & $\mathrm{C}$ & 6.27 & 0.92 & 14.67 & 0.00 \\
\hline & $\mathrm{B}$ & 6.26 & 0.71 & 11.34 & 0.00 \\
\hline \multirow[t]{2}{*}{ Werkdossiers op orde } & $\mathrm{C}$ & 6.48 & 0.65 & 10.03 & 0.00 \\
\hline & $\mathrm{B}$ & 6.48 & 0.84 & 12.96 & 0.00 \\
\hline \multirow[t]{2}{*}{ Toereikende notaspecificatie } & C & 6.34 & 2.73 & 43.06 & 0.00 \\
\hline & $\mathrm{B}$ & 6.28 & 1.44 & 22.93 & 0.00 \\
\hline \multirow[t]{2}{*}{ Belang van externe belanghebbenden vooropstellen } & $\mathrm{C}$ & 3.36 & -0.26 & -7.74 & 0.09 \\
\hline & B & 4.56 & 0.35 & 7.68 & 0.00 \\
\hline
\end{tabular}


Functionele kwaliteitselementen (vervolg)

\begin{tabular}{|c|c|c|c|c|c|}
\hline Kwaliteitselement & $\mathbf{C} / \mathbf{B}$ & $\mathbf{W}$ & $\mathbf{W}-\mathbf{P}$ & $(\mathbf{W}-\mathbf{P}) / \mathbf{W}$ & p-waarde \\
\hline \multirow[t]{2}{*}{ Op tijd komen } & $\mathrm{C}$ & 6.17 & 0.65 & 10.53 & 0.00 \\
\hline & $\mathrm{B}$ & 5.81 & 0.33 & 5.68 & 0.01 \\
\hline \multirow[t]{2}{*}{ Weinig wisselend controleteam } & $\mathrm{C}$ & 5.90 & 0.61 & 10.34 & 0.01 \\
\hline & $\mathrm{B}$ & 5.89 & 0.37 & 6.28 & 0.00 \\
\hline \multirow[t]{2}{*}{ Oprechte belangstelling voor problemen } & $\mathrm{C}$ & 6.27 & 0.30 & 4.78 & 0.03 \\
\hline & $\mathrm{B}$ & 6.34 & 0.64 & 10.09 & 0.00 \\
\hline \multirow[t]{2}{*}{ Dienstverlening gebeurt in één keer goed } & $\mathrm{C}$ & 6.13 & 0.81 & 13.21 & 0.00 \\
\hline & $\mathrm{B}$ & 6.08 & 0.51 & 8.39 & 0.00 \\
\hline \multirow[t]{2}{*}{ Nooit te druk hebben voor vragen cliënten } & $\mathrm{C}$ & 5.55 & 0.08 & 1.44 & 0.33 \\
\hline & $\mathrm{B}$ & 5.55 & 0.25 & 4.50 & 0.03 \\
\hline \multirow[t]{2}{*}{ Bereidwilligheid tot helpen } & $\mathrm{C}$ & 6.27 & 0.32 & 5.10 & 0.02 \\
\hline & $\mathrm{B}$ & 6.22 & 0.54 & 8.68 & 0.00 \\
\hline \multirow[t]{2}{*}{ Van te voren precieze afspraken voor werkzaamheden } & $\mathrm{C}$ & 6.31 & 0.39 & 6.18 & 0.00 \\
\hline & $\mathrm{B}$ & 6.14 & 0.78 & 12.70 & 0.00 \\
\hline \multirow[t]{2}{*}{ Eén centraal aanspreekpunt } & $\mathrm{C}$ & 6.11 & 0.29 & 4.75 & 0.04 \\
\hline & $\mathrm{B}$ & 6.48 & 0.66 & 10.19 & 0.00 \\
\hline \multirow[t]{2}{*}{ Voortdurend bereikbaar voor vragen } & $\mathrm{C}$ & 5.77 & 0.39 & 6.76 & $0.0 \mathrm{I}$ \\
\hline & $\mathrm{B}$ & 5.84 & 0.69 & 11.82 & 0.00 \\
\hline \multirow[t]{2}{*}{ Prompte dienstverlening } & $\mathrm{C}$ & 6.07 & 0.56 & 9.23 & 0.00 \\
\hline & $\mathrm{B}$ & 5.86 & 0.39 & 6.66 & 0.00 \\
\hline \multirow[t]{2}{*}{ Regelmatige bespreking van de bevindingen } & $\mathrm{C}$ & 5.99 & 0.65 & 10.85 & 0.00 \\
\hline & $\mathrm{B}$ & 6.33 & 0.87 & 13.74 & 0.00 \\
\hline \multirow[t]{2}{*}{ Vertrouwenssfeer wekken } & $\mathrm{C}$ & 6.33 & 0.50 & 7.90 & 0.00 \\
\hline & $\mathrm{B}$ & 6.33 & 0.49 & 7.74 & 0.00 \\
\hline \multirow[t]{2}{*}{ Gerust laten voelen bij het zaken doen } & $\mathrm{C}$ & 6.25 & 0.42 & 6.72 & 0.00 \\
\hline & $\mathrm{B}$ & 6.58 & 0.80 & 12.16 & 0.00 \\
\hline \multirow[t]{2}{*}{ Belang van de cliënt voorop stellen } & $\mathrm{C}$ & 5.98 & 0.47 & 7.86 & 0.01 \\
\hline & $\mathrm{B}$ & 6.07 & 0.64 & 10.54 & 0.00 \\
\hline \multirow[t]{2}{*}{ Hoffelijke en vriendelijke medewerkers } & $\mathrm{C}$ & 5.69 & $-0.35(!)$ & -6.15 & 0.01 \\
\hline & B & 5.48 & -0.07 & -1.28 & 0.32 \\
\hline \multirow[t]{2}{*}{ Persoonlijke aandacht } & $\mathrm{C}$ & 6.25 & 0.97 & 15.52 & 0.00 \\
\hline & $\mathrm{B}$ & 6.01 & 0.36 & 5.99 & 0.00 \\
\hline \multirow[t]{2}{*}{ Specifieke wensen van de cliënt kennen } & $C$ & 5.99 & 0.35 & 5.84 & 0.01 \\
\hline & $B$ & 5.93 & 0.42 & 7.08 & 0.01 \\
\hline
\end{tabular}

B $=$ bankiers $\mid \mathrm{n}=89]$;

$\mathrm{W} \quad=$ gemiddelde van gewenste prestatieniveau;

W-P = gemiddelde (absolute) kwaliteitskloof;
$\mathrm{C}=$ cliënten $[\mathrm{n}=66]$

$\mathrm{P}=$ gemiddelde van gepercipieerde prestatieniveau

$(\mathrm{W}-\mathrm{P}) / \mathrm{W}=$ gemiddelde relatieve kwaliteitskloof (in \%)

* De (eenzijdige) p-waarde is gegeven op basis van een paarsgewijze t-test tussen het niveau van de gewenste prestatie en het niveau van de gepercipieerde prestatie. 